\title{
Use of Alkali-activated Aluminosilicatematerialto Enhancebiogas Production from Acidic Whey
}

\author{
K. Rugele ${ }^{1,2, *}$, E. Skripsts ${ }^{1}$, L. Mezule ${ }^{1}$, P. Pitk ${ }^{3}$, D. Bajare ${ }^{4}$ and T. Juhna ${ }^{1}$ \\ ${ }^{1}$ Department of Water Engineering and Technology, Riga Technical University, Azenes street 16/20, Riga, LV-1016, Latvia \\ ${ }^{2}$ Institute of General Chemical Engineering, Riga Technical University, Azenes 14, Riga, LV-1048, Latvia \\ ${ }^{3}$ Department of Chemistry, Tallinn University of Technology, Tallinn, Harjumaa, 12618, Estonia \\ ${ }^{4}$ Institute of Materials and Structures, Chair of Building Materials and Products, Riga Technical University, Azenes \\ street 16/20, Riga, LV-1048, Latvia
}

\begin{abstract}
The effect of the addition of novel alkali-activated material (AAM) granules to provide additional buffering capacity, $\mathrm{pH}$ stability and increased methane yields in batch scale anaerobic digestion was investigated.The experiments were carried out with $20 \%, 30 \%$ and $40 \%$ of acidic whey in $500 \mathrm{ml}$ batch reactors by a single addition of AAM granules (diameter from 2 to $8 \mathrm{~mm}$ ) at $37 \pm 0.5^{\circ} \mathrm{C}$ during 30 days. Presence of the AAM in the batch reactors allowedto maintain optimal $\mathrm{pH}$, thus increasingthe yield and rate of methane formation from acid whey.
\end{abstract}

Keywords: Acid whey, alkali-activated material, anaerobic digestion, biogas.

\section{INTRODUCTION}

Quantity of produced cottage cheese is rising every year. More than458368 tons of milk wasprocessed and 90 000tons of acidic cottage milk was generated in Latvia during 2010.Acidic whey is produced during cottage cheese production. Cheese whey is the lactose-rich by-product of cheese manufacturing. It makes up to about $80 \%$ of the original fermentation medium, and retains most of the milk fat, trace minerals, salts and vitamins [1].

Cheese whey is considered to be the most important pollutant in dairy industry, not only because of the high organic load, but also for the volume generated [2]. Disposal of the whey makes up a significant part of the environmental problem and contributes substantially to the pollution of surface waters and soil [3].The whey is mostly used for animal feeding or poured out on agricultural lands. With increasing cheese production alternative treatment possibilities besides using it as feed for animals are required.

Cheese whey can be utilized in many ways. Lactose and whey protein can be recovered separately and used further for other applications. However, it is usually unprofitable due to the high energy cost and the complexity of the process. As the whey represents a potential energy source, anaerobic digestion offers an excellent approach in terms of both energy conservation and pollution control [4, 5]. encountered difficulties in maintaining stable operation conditions [6, 7]. It is characterized by a very high organic

*Address correspondence to these authors at the Department of Water Engineering and Technology, Riga Technical University, Azenes street 16/20, Riga, LV-1048, Latvia,; Tel: +371 26536486;

E-mail: kristine.rugele@rtu.lv load and low buffer capacity; consequently, the direct anaerobic treatment of the raw whey can lead to rapid acidification which results in low biogas productivity [7-9], thereforesupplemental alkalinity is required to avoid anaerobic process failure [10].

Immobilization of microbial consortia is important for optimum functioning of anaerobic treatment systems, so that the concentrations of the intermediates are sufficiently low for efficient carbon cycling. It has been reported that a distance of less than $1 \mu \mathrm{m}$ between syntrophic bacteria and methanogens is a prerequisite for oxidation of fatty acids, allowing the transfer of reducing equivalents to the methanogens $[11,12]$. Clay minerals and other surface active particles have been reported to influence microbial and enzymatic transformation of a variety of substances [13]. A number of natural (sepiolites, zeolites, clays, etc.) or synthetic (polypropylene, other polymeric) matrices have been used for enhancing methane $\left(\mathrm{CH}_{4}\right)$ yields $[12,14]$.

The objective of this study was to test a new alkali-activated material produced from aluminium scrap recycling wastes, glass waste and calcined clay for enhancement of acid whey anaerobic digestion in batch scale experiments: stabilization of the process $\mathrm{pH}$, support media for bacterial growth and improved yield and rate of methane production.

\section{MATERIALS AND METHODS}

Whey

Acid cheese whey was supplied by a dairy product manufacturer "Smiltenes Piens Ltd". The whey samples were provided by the manufacturing company, collected in 
five litter containers and stored at $4^{\circ} \mathrm{C}$ for maximum two weeks to avoid changes of the chemical composition.

\section{Inoculum}

Digestate from continuous laboratory fermenter, providing HRT (Hydraulic retention time) of 50 days, fed with cattle manure and alfalfa granuleswas used as the inoculum. The digestate was kept at $37^{\circ} \mathrm{C}$ in the incubator for 2 days prior to the experiments in order to minimize the possible influence on the experimental results. Microbial biomass content was evaluated with Fluorescent in situ hybridization (FISH) to determine the initial concentration of methanogens in the digestate. The samples were prepared according to the protocol described by Rugele et al. [15], with the exception that sample analyses were performed with epifluorescence microscope (Leica DM6000B) equipped with a 100-W power supply, halogen lamp, filter sets for DAPI (4',6-diamidino-2-phenylindole; BP 340-380; LP 425), FITC (BP 480/40; BP 527/30) and CY3 (PB 545/40; BP 610/75), and a camera (DFC450 C, Leica). For image processing Image Pro Premier software (Media Cybernetic Inc., Silver Spring, MD) was used.

\section{Alkali activated material}

AAM was produced from a pre-treated ceramics matrix byInstitute of Materials and Structures in Riga Technical University and was intended to serve as both a buffering agent and support media for biomass attachment during the anaerobic digestion process. No additional $\mathrm{pH}$ control in the reactors was performed.

The material consisted of aluminium recycling waste obtained from aluminium scrap recycling factory, recycled silicate glassobtained from fluorescent lamp recycling process, commercially availablecalcinatedmetacaolin clay supplemented withwater glass $\left(\mathrm{Na}_{2} \mathrm{SiO}_{3}+\mathrm{nH}_{2} \mathrm{O}\right)$, characterized by the silica modulus $\mathrm{Ms}=3.2\left(29.5 \mathrm{wt} \% \mathrm{SiO}_{2}, 9 \mathrm{wt} \%\right.$ $\mathrm{Na}_{2} \mathrm{O}, 61.5 \mathrm{wt} \% \mathrm{H}_{2} \mathrm{O}$ ), and commercially available alkali flakes with a purity of $97 \%$. Sodium hydroxide was added to sodium silicate solution for preparing alkali activator having silica moduli $\left(\mathrm{Ms}=\mathrm{SiO}_{2} / \mathrm{Na}_{2} \mathrm{O}\right)$ of 0.17 . Activator to dry mix ratio of 0.62 was used to prepare AAM. Material was moulded and curred at temperature $80^{\circ} \mathrm{C}$ for $24 \mathrm{~h}$.

Alkali activated material had a surface area of $6.306 \mathrm{~m}^{2} / \mathrm{g}$, open porosity $29-32 \%$ and total porosity of $82-83 \%$. The material consisted of granules in range of $2-8 \mathrm{~mm}$ with similar fraction distribution.

\section{Batch Experiments}

Batch experiments were carried out inglass reactors with a working volume of $500 \mathrm{ml}$. The samples were incubated at $37 \pm 0.5^{\circ} \mathrm{C}$. During all experiments biogas production and gas content was controlledafter each 12 hours. Total solids (TS), volatile total solids (VS), $\mathrm{pH}$ and chemical oxygen demand (COD)were measured both for the whey and inoculumat the beginning and at the end of the fermentation for each reactor. AAM were added at the beginningof experiments without any previous $\mathrm{pH}$ correction. The ratio (g/g) between AAM granules and CODof substrate addedwere $0.05,0.07$ and 0.1 . Substrate toinoculumsratio was between 0.2-0.4. 20, 30 and $40 \mathrm{vol} \%$ of whey content in the system was evaluated. Dilution process or any other pretreatmentof whey was not used.Control reactors only with inoculum were also run to determine the background gas production.

\section{Analysis}

TSweredetermined by drying a sample at $105^{\circ} \mathrm{C}$ for 24 hours. VS and ash were analyzedat $550^{\circ} \mathrm{C}$ in muffle furnace for 150 minutes.COD was analyzed with Hach Lange cuvettes test.The $\mathrm{pH}$ was measured using Lutron $\mathrm{pH}-208$. The capacity of AAM to neutralise acid by $\mathrm{NaOH}$ leaching was measured and titration method with $0.1 \mathrm{M} \mathrm{HCl}$ was applied to determine released $\mathrm{NaOH}$ in distilled water from alkaline granules daily.

For gas collection and measurement PVF sampling bags (TEDLAR) and $60 \mathrm{ml}$ syringes were used. Biogas composition (methane and carbon dioxide) was measured with infrared analyser (Gasboard 3200L).

BET method (QuadraSorb, USA)was used to determine the surface area of AAM. The materialwas characterized withX-ray diffraction (XRD) (CuK radiation, RigakuUltima, Japan) and scanning electron microscopy (SEM) (Tescan Mira/ Lmu, Czech Republic). Elemental analysis was performed withenergy dispersive spectroscopy (EDS).

\section{Statistics Analyses}

In order to determine if the experimental results for batch tests(with and without AAM) at different whey concentrationswere significantly different, the student's t-test was used to test the null (no difference) hypothesis of quality at a 95\% confidence level. For all analysis MS EXCEL software was used.

\section{RESULTS AND DISCUSSION}

\section{Alkali Activated Material}

Two following methods are currently being used in practice to deal with the problem of acidification during the production of methane from acid whey: dilution of cheese whey [1] and $\mathrm{pH}$ control [16]. Fermentation in the batch reactors is usually carried out without active $\mathrm{pH}$ control, but with a high initial buffer concentrations or alkalinity supplementation to prevent excessive $\mathrm{pH}$-drifts during the cultivation [17]. This approach, although inexpensive and operational, initially create highly alkaline conditions, thus, may inhibit the growth of microorganisms and the start of the fermentation [18].

To address this problem, we investigated whether the addition of specially prepared alkaline material (AAM) which slowly releases hydroxyl ions allowsto stabilise $\mathrm{pH}$ and improve fermentation process.

Before the fermentation experiments, the capacity of AAM to neutralise acid was estimated (Fig. 1). The results showed that $\mathrm{NaOH}$ increased rapidly for the first three days, then for the next twenty days the release rate declined due to mostly dissolved base from the granules.Furthermodification of the material is required to improve more stable base 


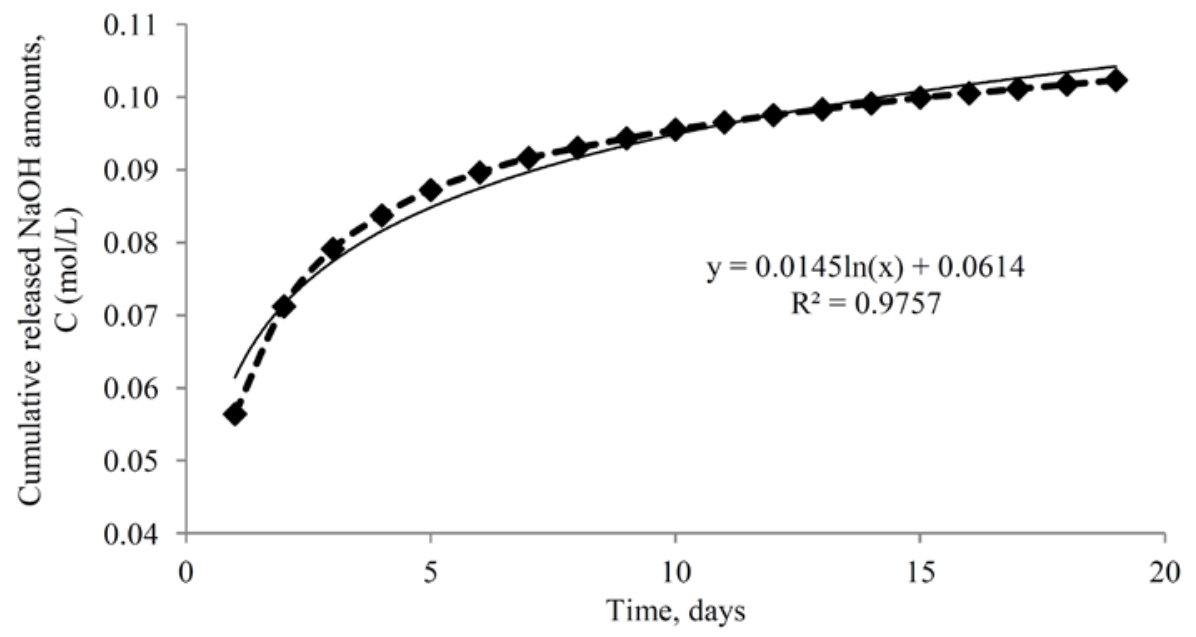

Fig. (1). Base concentration for daily replaced water, where AAM granules were immersed.

release the first days and to reach linear behaviour of the curve.

\section{Batch Experiment}

Characteristic values of chemical analysis of the acid whey and inoculum used for studies showed high levels of TS (5.68\%) and VS (4.92\%) for the whey, while the inoculum had a much lower TS and VS, 2.86\% and 1.62\% respectively (Table 1). Acid whey showed to bea high strength organic substrate, since COD value was as high as $73.3 \mathrm{~g} \mathrm{O}_{2} / \mathrm{L}$. The main component of the organic compounds in the whey was lactose contributing $4.85 \%$ of total volume.

Table 1. Chemical composition of inoculum and whey.

\begin{tabular}{|c|c|c|}
\hline Parameter & Inoculum & Whey \\
\hline \hline $\mathrm{pH}\left(20{ }^{\circ} \mathrm{C}\right)$ & 8.01 & 4.72 \\
\hline Total solids (\% w/w) & 2.86 & 5.68 \\
\hline Volatile solids (\% w/w) & 1.62 & 4.92 \\
\hline $\mathrm{COD}_{\text {total }}\left(\mathrm{g} \mathrm{O}_{2} / \mathrm{L}\right)$ & - & 73.3 \\
\hline $\mathrm{COD}_{\text {soluble }}\left(\mathrm{g} \mathrm{O}_{2} / \mathrm{L}\right)$ & - & 29.5 \\
\hline Ash $(\% \mathrm{w} / \mathrm{w})$ & 0.59 & 0.69 \\
\hline Protein $(\% \mathrm{w} / \mathrm{w})$ & - & 0.3 \\
\hline Non-protein nitrogen $(\% \mathrm{w} / \mathrm{w})$ & - & 0.2 \\
\hline Lactose $(\% \mathrm{w} / \mathrm{w})$ & - & 4.85 \\
\hline Fat $(\% \mathrm{w} / \mathrm{w})$ & - & 0.05 \\
\hline
\end{tabular}

Microbiological analyses of the inoculum showed high initial microbial concentrations $\left(>10^{10}\right.$ cells $/ \mathrm{ml}$ ) of various shaped Eubacteria and Archaebacteria - rods, long rods andcoccoid forms (Fig. 2). Archaeaconcentration in the inoculum ranged from 62 to $77 \%$ from all microorganisms.

The experiments on batch anaerobic digestion showed thatwhey concentration and AAM addition influence theoverallmethane production and cumulativeincrease
(Fig. 3). The addition of the AAM improvedbiogas production and resulted in more stable cumulative methane curves. The obtained dataindicatedthat AAM hadhigher application potential in the reactors withaincreased acid whey concentration due tomore significant difference between rectors with and without material additive. The fermentation process with $20 \%$ whey was shorter for 4 days by addition of AAM in the reactor comparedto without AAM fermentation. However, the improvement of methane production was not statistically significant ( $\mathrm{p}>0.05)$.

Methane production with $30 \%$ whey and AAM is very stable and fast, maximal methane content in biogas was around $80 \%$ and was reached 10 days earlier when compared to the system without AAM added. In samples with $40 \%$ whey (AAM positive) the initial methane production was much lower than to samples with $30 \%$ whey (AAM positive).

The addition of support materials like magnesium or aluminium silicates to anaerobic digestion processes have been reported to lead to higher methane yields or better gas quality [19].In this study the methane yield did not vary significantly ( $p>0.05$ ) when different whey concentrations were used and supplied with AAMHowever,a slight increase in methaneconcentration was observed for $30 \%$ and $40 \%$ whey samples the methane concentration increased up to $38.6 \%$ (Table 2 ) whencompared to the reactor without AAM.

Table 2. The methane yield with and without the addition of AAM and different concentrations of the whey (after 35 days).

\begin{tabular}{|c|c|}
\hline Substrate & Methane yield, ml $_{\text {CH4 }}$ g COD \\
\hline \hline $20 \%$ whey +AAM & $301.78 \pm 18.9$ \\
\hline $30 \%$ whey +AAM & $313.97 \pm 21.5$ \\
\hline $40 \%$ whey +AAM & $314.93 \pm 25.9$ \\
\hline 20\% whey & $289.86 \pm 20.4$ \\
\hline $30 \%$ whey & $293.97 \pm 17.9$ \\
\hline $40 \%$ whey & $227.26 \pm 25.8$ \\
\hline
\end{tabular}




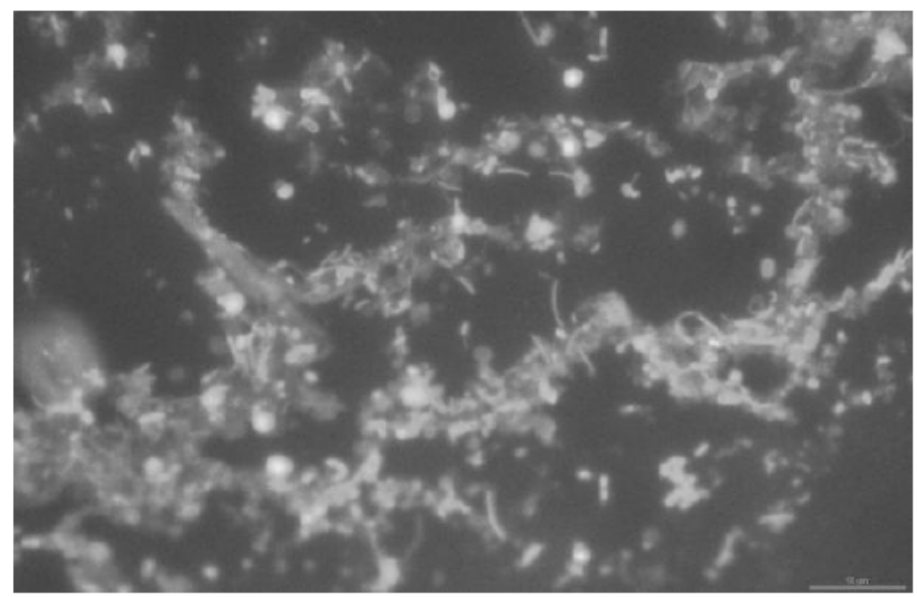

Fig. (2). Microbiological composition of the inoculum (10 $\mu \mathrm{l}$ of the sample stained with DAPI).
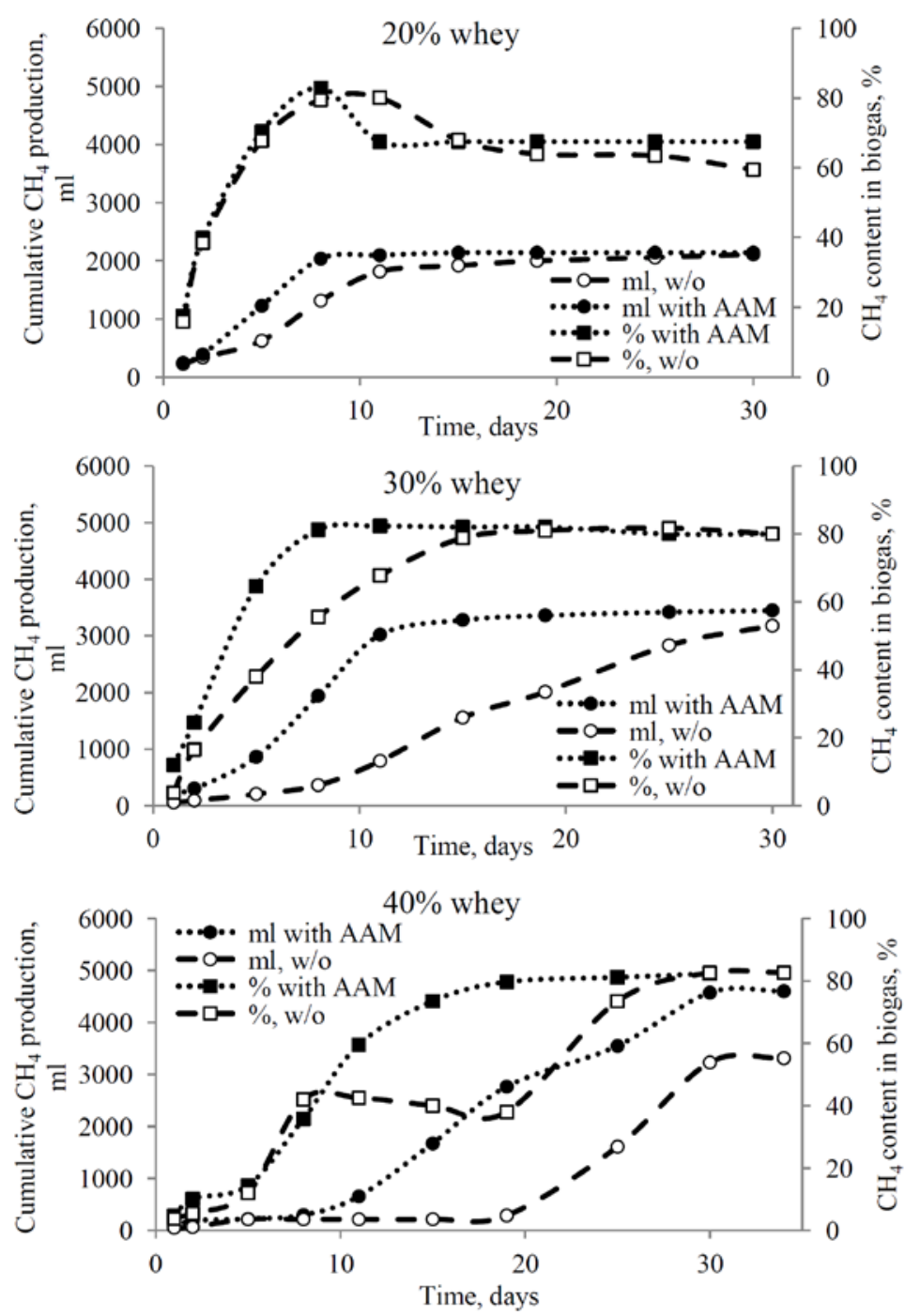

Fig. (3). Methane cumulative curves and content in biogas for acid whey anaerobic digestion process with or without alkali-activated material atdifferent whey concentrations - 20\%, 30\% and $40 \%$.

The statistical analysis showed no significant differences between the reactors with $20 \%$ whey concentration and AAM presence, but showed significant differences between reactors with $30 \%$ and $40 \%$ whey and AAM presence $(\mathrm{p}<0.05)$. 
Table 3. The results of TS, VS, ash and $\mathrm{pH}$ at the end of experiments.

\begin{tabular}{|c|c|c|c|c|}
\hline Material & TS [g/kg] & VS [g/kg] & Ash [\%] & $1.25 \pm 0.3$ \\
\hline \hline $20 \%$ whey +AAM & $24.17 \pm 0.5$ & $11.84 \pm 0.2$ & $1.14 \pm 0.2$ & $8.03 \pm 0.08$ \\
\hline $20 \%$ whey & $24.06 \pm 0.4$ & $12.63 \pm 0.2$ & $1.21 \pm 0.2$ & $7.92 \pm 0.11$ \\
\hline $30 \%$ whey +AAM & $22.70 \pm 0.5$ & $10.61 \pm 0.3$ & $0.94 \pm 0.1$ & $7.04 \pm 0.09$ \\
\hline $30 \%$ whey & $21.45 \pm 0.3$ & $12.45 \pm 0.1$ & $1.18 \pm 0.1$ & $7.86 \pm 0.06$ \\
\hline $40 \%$ whey +AAM & $21.86 \pm 0.7$ & $10.09 \pm 0.4$ & $0.94 \pm 0.3$ & $7.55 \pm 0.14$ \\
\hline
\end{tabular}

The TS values were similar ( $p>0.05$ ) in the experiments with and without the AAM at the end of the experiments; however, VS data showed that in the experiments without the AAM it was higher which indicated on the ability of AAM to promote the degradation of organics (Table 3 ). The amount of ash in the experiments with AAM was higher and it could be explained by the dissolving of $\mathrm{Na}^{+}$from the AAM in the fermentation substrate.

\section{AAM Investigations}

The mineralogical changes of the AAM during the fermentation process were also examined. The alkaline material had a fairly amorphous structure.XRD data showedthat there were minor changes in the mineralogical composition of AAM and some peaks disappeared after the fermentation. It was established that the peaks could not be
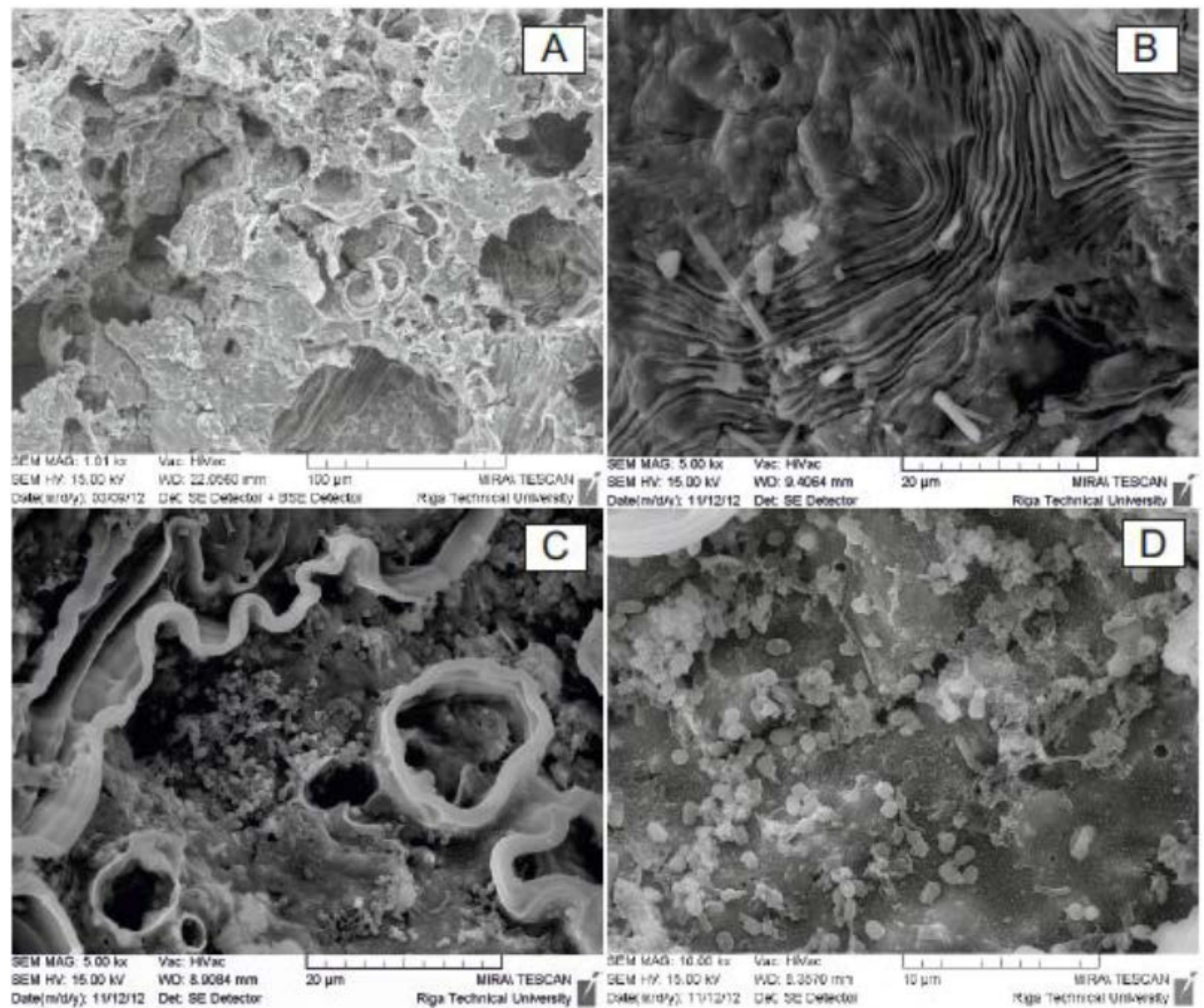

Fig. (4). Microstructure of AAM studied with SEM. The AAM before the fermentation is shown in a) and $\mathbf{b}$ ). The material after the fermentation is shown in c) and d). Photographs were taken at 1000 (a), 5000 (b,c), 10000 (d) $\times$ amplification. 
attributed to $\mathrm{NaOH}$, however, additional experiments would be necessary to establish the nature of the peaks.

The AAM before and after the fermentations was also subjected to the analyses using SEM (Fig. 4). The AAM displays a porous material structure with wide range of pore diameter.EDX results indicate that compounding elements as $\mathrm{Al}, \mathrm{Si}, \mathrm{Na}$ and $\mathrm{O}$ were present at material structure; however, these elements should not affect the growth of microorganisms negatively.The crystals of $\mathrm{NaOHwere}$ visible on the material before the fermentation (Fig. 4, a and b) and SEM analyses showed that they disappear after the fermentation. It was also demonstrated that biofilm was present on the granules at the end of the experiments (Fig. 4, c and d).

The immobilization of microorganisms on various zeolite types has been claimed to be beneficial and expanding the possibilities to support the process [20]. In our study during cultivation over 30 days, two dominant cell morphologies were observed - coccoid form with dimensions of approximately $0.6 \mu \mathrm{m}$ in diameter and rod-shaped forms in length of approximately $2 \mu \mathrm{m}$ similar to those observed in the initial inoculum. With the increase of the population density on the given support, there is a greater chance of cross-feeding, co-metabolism and interspecies hydrogen and proton transfer, which may further stimulate the growth of microcolonies [21]. SinceAAM contains different concentrations of trace metals $\left(\mathrm{Mg}^{2+}, \mathrm{Ca}^{2+}, \mathrm{Fe}^{2+}, \mathrm{K}^{+}\right.$cations), it is able to enhance microbial activity [22].

The AAM material maintained $\mathrm{pH}$, and according to the titration analyses, it was due to a constant dissolution of $\mathrm{NaOH}$ crystals.

The novel material is produced from recycled wastes, so even if it requires activation with $\mathrm{NaOH}$ and temperature, the total cost of material is expected to be lower than for other technologies, which are used in production ofmethane from acid whey. AAM added to the reactor system before the start of experiments required no additional $\mathrm{pH}$ adjustment, which allowedto introduceless sophisticated pH control.

\section{CONCLUSION}

It was shown that alkali-activated material from recycled wastes could be used as new progressive material for enhancement of the anaerobic digestion process. The addition of AAM to anaerobic digestion process makes it more stable and faster, so itis possible to operate continuous reactor system at higher acid whey loading rate. Biogas production and anaerobic digestion process stability can be significantly improved by the use of a novel alkali-activated material in the form of granules, especially when high acid whey concentrations up to $40 \%$ with low pH are applied.

The addition of alkali-activated material to acidic whey at concentration of $30 \%$ increased methane yield by $12.5 \%$ and decreased biomass adaption time when compared to non AAM test. At acidic whey concentration of $40 \%$,the process without AAM was significantly inhibited when compared to the process with the AAM addition.

\section{CONFLICT OF INTEREST}

The authors confirm that no conflicts of interest are associated with this article.

\section{ACKNOWLEDGEMENTS}

This work has been supported by ESF project "Involvement of Human Resources for Development of Integrated Renewable Energy Resources Energy Production System”, No.Nr.2013/0014/1DP/1.1.1.2.0/13/APIA/VIAA/ 026.

\section{REFERENCES}

[1] Ferchichi M, Crabbe E, Gil GH, Hintz W, Almadidy A. Influence of initial $\mathrm{pH}$ on hydrogen production from cheese whey. J Biotechnol 2005; 120: 402-09.

[2] Carvalho F, Prazeres AR, Rivas J. Cheese whey wastewater: characterization and treatment. Sci Total Environ 2004; 445-446: 385-96.

[3] Kosseva MR, Kent CA, Lloyd DR. Thermophilic bioremediation strategies for a dairy waste. Biochem Engin J 2003; 15: 125-30.

[4] Ben-Hassan RM, Ghaly AE. Continuous propagation of Kluyveromycesfragilis in cheese whey for pollution potential reduction. Appl Biochem Biotechnol 1994; 47: 89-105.

[5] Patel C, Madamwar D. Biomethanation of salty cheese whey using ananaerobic rotating biological contact reactor. J Ferment Bioeng 1997; 83: 502-04.

[6] Yan JQ, Liao PH, Lo KV. Methane production from cheese whey. Biomass 1988; 17: 185-02.

[7] Malaspina F, Cellamare CM, Stante L, Tilche A. Anaerobic treatment of cheese whey with a downflow-upflow hybrid reactor. Bioresour Technol 1996; 55: 131-39.

[8] Ghaly AE. A comparative study of anaerobic digestion of acid cheese whey and dairy manure in a two-stage reactor. Bioresour Technol 1996; 58: 61-72.

[9] Saddoud A, Hassairi I, Sayadi S. Anaerobic membrane reactor with phase separation for the treatment of cheese whey. Bioresour Technol 2007; 98: 2102-08.

[10] Lo KV, Liao PH. Digestion of cheese whey with anaerobic rotating biological contact reactor. Biomass 1986; 10: 243-52.

[11] Stams AJM. Metabolic interactions between anaerobic bacteria in methanogenic environments. Anton Leeuw 1994; 66: 271-94.

[12] Chauhan A, Ogram A. Evaluation of support matrices for immobilization of anaerobic consortia for efficient carbon cycling in waste regeneration. Biochem Biophys Res Com 2005; 327: 88493.

[13] Milán Z, Villa P, Sánchez E, et al.. Effect of natural and modified zeolite addition on anaerobic digestion of piggery waste. Water Sci Technol 2003; 48: 263-69.

[14] Lalov G, Krysteva AM, Phelouzat JL. Improvement of biogas production from vinasse via covalently immobilzed methanogens. Bioresour Technol 2001; 79: 83-5.

[15] Rugele K, Mezule L, Dalecka B, Larsson S, Vanags J, Rubulis J. Application of fluorescent in situ hybridisation for monitoring methanogenic archaea in acid whey anaerobic digestion. Agron Research 2013; 11: 373-80.

[16] Ghaly AE, Ramkumar DR, Sadaka SS, Rochon JD. Effect of reseeding and $\mathrm{pH}$ control on the performance of a two-stage mesophilic anaerobic digester operating on acid cheese whey. Can Agr Eng 2002; 42: 173-83.

[17] Mockaitis G, Ratusznei SM, Rodrigues AD, Zaiat M, Foresti E. Anaerobic whey treatment by a stirred sequencing batch reactor (ASBR): effects of organic loading and supplemented alkalinity. J Environ Manag 2006; 79: 198-06.

[18] Fang C, Boe K, Angelidaki I. Anaerobic co-digestion of desugared molasses with cow manure: focusing on sodium and potassium inhibition. Bioresour Technol 2001; 102: 1005-11. 
[19] Pande DR, Fabiani C. Feasibility studies on the use of a naturally occurring molecular sieve for methane enrichment from biogas. Gas Sep Purif 1989; 3: 143-47.

[20] Murray WD, van den Berg L. Effect of support material on the development of microbial fixed films converting acetic acid to methane. J Appl Bacteriol 1981; 51: 257-65.
[21] Montalvo S, Guerrero-Borja R, Sánchez E, Milán Z, Cortés I, Angeles M. Application of natural zeolites in anaerobic digestion processes: a review. Bioresour Technol 2012; 58: 125-33.

[22] Weiss S, Tauber M, Somitsch W, Meincke R, Müller H, Berg G, Guebitz GM. Enhancement of biogas production by addition of hemicellulolytic bacteria immobilised on activated zeolite. Water Res 2010; 44: 1970-80.

Received: July 22, 2014

(c) Rugele et al.; Licensee Bentham Open.

This is an open access article licensed under the terms of the Creative Commons Attribution Non-Commercial License (http://creativecommons.org/licenses/ by-nc/3.0/) which permits unrestricted, non-commercial use, distribution and reproduction in any medium, provided the work is properly cited. 